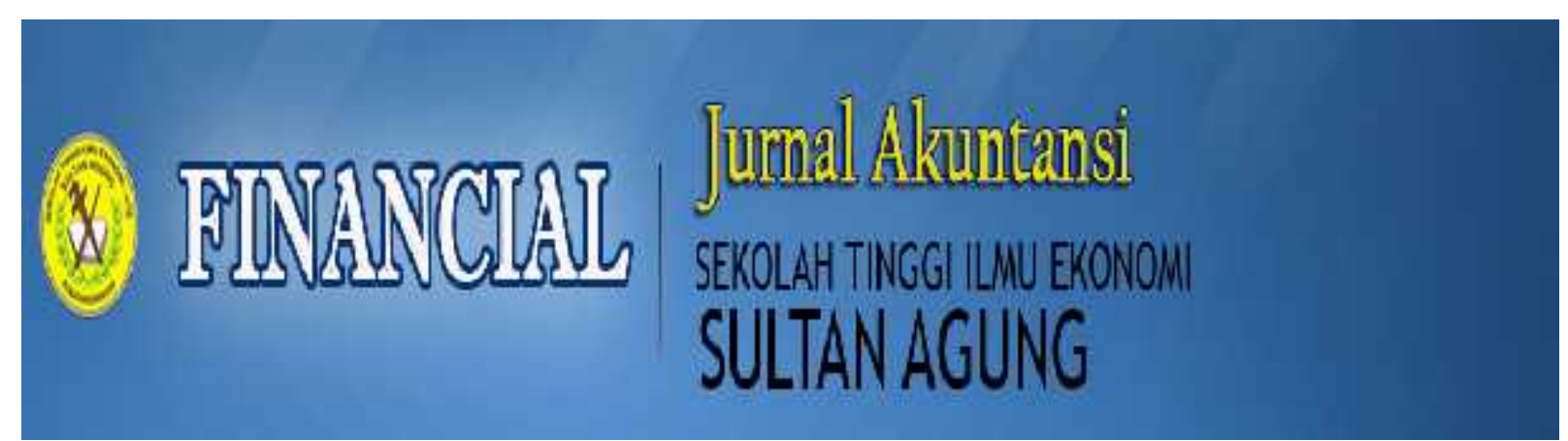

\title{
PENGARUH LIKUIDITAS DAN PROFITABILITAS TERHADAP NILAI PERUSAHAAN DENGAN KEBIJAKAN DIVIDEN SEBAGAI VARIABEL MODERATING PADA PERUSAHAAN SUB SEKTOR MAKANAN DAN MINUMAN YANG TERDAFTAR DI BURSA EFEK INDONESIA
}

\author{
Oleh : \\ Evryl Claudya Tarigan \\ S1 Akuntansi \\ Jubi, Ady Inrawan, Supitriyani
}

Abstrak

Tujuan penelitian ini adalah untuk mengetahui: 1. Gambaran likuiditas, profitabilitas, kebijakan dividen, dan nilai perusahaan. 2. Pengaruh likuiditas dan profitabilitas terhadap nilai perusahaan baik secara simultan maupun parsial. 3. Kemampuan kebijakan dividen dalam memoderasi hubungan likuiditas dan profitabilitas dengan nilai perusahaan pada Perusahaan Sub Sektor Makanan dan Minuman yang terdaftar di Bursa Efek Indonesia secara parsial. Penelitian ini dilakukan dengan metode analisis deskriptif kualitatif dan analisis deskriptif kuantitatif. Pengumpulan data dilakukan dengan metode dokumentasi. Teknik analisis yang digunakan adalah uji asumsi klasik, analisis regresi linear berganda, koefisien korelasi dan determinasi serta uji hipotesis.

Hasil penelitian ini dapat disimpulkan sebagai berikut: 1. Likuiditas, profitabilitas, dan kebijakan dividen mengalami peningkatan sedangkan nilai perusahaan mengalami penurunan. 2. Hasil pengujian regresi linear berganda tanpa variabel moderating diketahui bahwa likuiditas berpengaruh negatif, sementara profitabilitas berpengaruh positif terhadap nilai perusahaan. 3. Hasil pengujian regresi linear berganda dengan variabel moderating diketahui bahwa kebijakan dividen memperkuat hubungan likuiditas dengan nilai perusahaan, sementara kebijakan dividen memperlemah hubungan profitabilitas dengan nilai perusahaan. 4. Hasil uji hipotesis pertama dapat disimpulkan bahwa likuiditas dan profitabilitas berpengaruh signifikan terhadap nilai perusahaan secara simultan. Sedangkan secara parsial likuiditas berpengaruh tidak signifikan dan profitabilitas berpengaruh signifikan terhadap nilai perusahaan 5. Hasil uji hipotesis kedua dapat disimpulkan bahwa kebijakan dividen mampu memoderasi namun tidak signifikan hubungan likuiditas dan profitabilitas dengan nilai perusahaan secara parsial.

Saran yang dapat diberikan adalah sebaiknya perusahaan mengelola aset lancarnya secara efisien, lebih produktif dalam mengelola aset dalam meningkatkan laba perusahaan, menjaga profitabilitas tetap meningkat dan meningkatkan pembagian dividen.

Kata Kunci : Likuiditas, Profitabilitas, Kebijakan Dividen dan Nilai Perusahaan

\section{Abstract}

The aim of this research are to determine: 1 . The description of liquidity, profitability, dividend policy and firm value. 2. The effect of liquidity and profitability on the firm value either simultaneously or partially. 3. The ability of dividend policy in moderated the effect of liquidity and profitability on the firm value of the company at Food and Beverage Sub Sector Company Listed in Indonesia Stock Exchange partially. The research was using qualitative and quantitative desriptive analysis. The data collection was using documentation. The analysis techniques used are multiple linear regression, correlation coefficient, coefficient of determination, $F$ test and t test.

The results of this research concluded as follows: 1. Liquidity, profitability, and dividend policy has decreased, while firm value has decreased. 2. The results of multiple linear regression testing without moderating variable are known that liquidity has a negative effect, while profitability has a positive effect on the firm value. 3. The results of multiple linear regression test with moderating variable is known that dividend policy strengthens weakens the relationship of liquidity with firm value, while dividend policy weakens the relationship of profitability with firm value. 4 . The results of the first hypothesis can be concluded that liquidity and profitability has a significant effect on the firm value simultaneously. While partially liquidity has no significant effect and profitability has a significant effect on firm value 5. The result of the second hypothesis test can be concluded that dividend policy is able to moderate but there is no significant relationship between liquidity and profitability with the firm value partially. 
The result of this research suggests that the company should manage its current assets efficiently, be more productive in managing assets in increasing company profits, keeps profitability steady and increases dividend distribution.

Keywords: Liquidity, Profitability,Dividend Policy and Firm Value

\section{PENDAHULUAN}

\subsection{Latar Belakang Masalah}

Setiap perusahaan pastinya bertujuan untuk memperoleh laba agar dapat bertahan hidup dalam kondisi ekonomi apapun. Untuk mempertahankan hidup perusahaan, perusahaan harus mampu menciptakan nilai pasar atau nilai perusahaan yang mempunyai nilai jual tinggi. Tujuan utama perusahaan adalah meningkatkan kemakmuran pemilik perusahaan atau para pemegang saham melalui peningkatan nilai perusahaan. Nilai perusahaan mengukur keberhasilan perusahaan. Nilai perusahaan yang tinggi menunjukkan pasar percaya tidak hanya pada kinerja perusahaan. Semakin baiknya nilai perusahaan maka tingkat keyakinan investor semakin meningkat.

Nilai perusahaan dapat diukur dari berbagai aspek, salah satu rasio yang digunakan untuk mengukur nilai perusahaan adalah dengan menggunakan Price to Book Value (PBV). Dengan rasio ini dapat memberi informasi bagi manajemen bagaimana pandangan para investor terhadap risiko dan prospek masa depan perusahaan. Nilai perusahaan dapat dipengaruhi oleh beberapa faktor, salah satu faktor yang mempengaruhi nilai perusahaan adalah likuiditas. Dalam penelitian ini, likuiditas diukur dengan Current Ratio (CR) yang digunakan untuk menilai utang lancar dengan aktiva lancar.

Faktor lain yang dapat mempengaruhi nilai perusahaan adalah profitabilitas. Return On Asset (ROA) merupakan rasio profitabilitas yang digunakan dalam penelitian ini. Selain beberapa faktor di atas, faktor lain yang dapat mempengaruhi nilai perusahaan adalah kebijakan dividen. Dalam penelitian ini kebijakan dividen dijadikan sebagai variabel moderating yang diukur dengan Dividend Payout Ratio (DPR).

Tabel 1.1

Gambaran Rata-rata Likuiditas, Profitabilitas,

Kebijakan Dividen, dan Nilai Perusahaan pada Perusahaan Sub Sektor Makanan dan Minuman yang Terdaftar di Bursa Efek Indonesia Periode 2013-2016

\begin{tabular}{|c|c|c|c|c|}
\hline Tahun & $\begin{array}{c}\text { Likuid } \\
\text { itas }\end{array}$ & $\begin{array}{c}\text { Profitabi } \\
\text { litas }\end{array}$ & $\begin{array}{c}\text { Kebijakan } \\
\text { Dividen }\end{array}$ & $\begin{array}{c}\text { Nilai } \\
\text { Perusah } \\
\text { aan }\end{array}$ \\
\hline $\mathbf{2 0 1 3}$ & 1,35 & 0,06 & 0,28 & 3,30 \\
\hline $\mathbf{2 0 1 4}$ & 1,45 & 0,07 & 0,32 & 3,65 \\
\hline $\mathbf{2 0 1 5}$ & 1,65 & 0,06 & 0,33 & 2,91 \\
\hline $\mathbf{2 0 1 6}$ & 1,93 & 0,07 & 0,32 & 2,97 \\
\hline $\begin{array}{c}\text { Rata- } \\
\text { rata } \\
\text { (kali) }\end{array}$ & $\mathbf{1 , 5 9}$ & $\mathbf{0 , 0 6}$ & $\mathbf{0 , 3 1}$ & $\mathbf{3 , 2 1}$ \\
\hline Sumber: & $\begin{array}{l}\text { Laporan Keuangan Perusahan Sub } \\
\text { Sektor Makanan dan Minuman (Data } \\
\text { Diolah) }\end{array}$ \\
\hline
\end{tabular}

Berdasarkan Tabel 1.1 dapat dilihat bahwa nilai rata-rata Likuiditas cenderung meningkat sedangkan rata-rata Nilai Perusahaan mengalami fluktuasi dan cenderung menurun. Pada tahun 2015 terlihat likuiditas mengalami peningkatan dan nilai perusahaan mengalami penurunan. Hal ini tidak sejalan dengan pendapat Brigham dan Joel (2012:150), "jika rasio likuiditas, manajemen aset, manajemen hutang dan profitabilitas semuanya terlihat baik dan apabila kondisi ini berjalan terus menerus secara stabil maka rasio nilai pasar juga akan tinggi, harga saham kemungkinan tinggi sesuai dengan yang diperkirakan".

Kebijakan Dividen mengalami fluktuasi dan cenderung meningkat sedangkan nilai rata-rata Nilai Perusahaan mengalami fluktuasi dan cenderung menurun. Pada tahun 2015 terlihat kebijakan dividen mengalami peningkatan dan nilai perusahaan mengalami penurunan. Hal ini tidak sejalan dengan pendapat Myron Gordon dan John Lithner dalam Sudana (2011:169) berdasarkan teori bird in the hand, "kebijakan dividen berpengaruh positif terhadap harga saham".

\subsection{Rumusan Masalah}

1. Bagaimana gambaran likuiditas, profitabilitas, kebijakan dividen dan nilai perusahaan pada Perusahaan Sub Sektor Makanan dan Minuman yang terdaftar di Bursa Efek Indonesia.

2. Bagaimana pengaruh likuiditas dan profitabilitas terhadap nilai perusahaan pada Perusahaaan Sub Sektor Makanan dan Minuman yang terdaftar di Bursa Efek Indonesia baik secara simultan maupun parsial.

3. Bagaimana kemampuan kebijakan dividen dalam memoderasi hubungan likuiditas dan profitabilitas dengan nilai perusahaan pada Perusahaan Sub Sektor Makanan dan Minuman yang terdaftar di Bursa Efek Indonesia secara parsial.

\subsection{Tujuan Penelitian}

1. Untuk mengetahui gambaran likuiditas, profitabilitas, kebijakan dividen dan nilai perusahaan pada Perusahaan Sub Sektor Makanan dan Minuman yang terdaftar di Bursa Efek Indonesia.

2. Untuk mengetahui pengaruh likuiditas dan profitabilitas terhadap nilai perusahaan pada Perusahaan Sub Sektor Makanan dan Minuman yang terdaftar di Bursa Efek Indonesia baik secara simultan maupun parsial.

3. Untuk mengetahui kemampuan kebijakan dividen dalam memoderasi hubungan likuiditas dan profitabilitas dengan nilai 
perusahaan pada Perusahaan Sub Sektor Makanan dan Minuman yang terdaftar di Bursa Efek Indonesia secara parsial.

\subsection{Metodologi Penelitian}

Penelitian ini menggunakan data sekunder yang diakses dari situs www.idx.co.id. Desain penelitian yang digunakan adalah penelitian kepustakaan (library research). Populasi dalam penelitian ini berjumlah 14 perusahaan dan yang menjadi sampel penelitian sebanyak 3 perusahaan. Teknik pengumpulan data yang digunakan adalah metode dokumentasi. Teknik analisa data yang digunakan adalah uji asumsi klasik, analisis deskriptif kualitatif dan analisis deskriptif kuantitatif.

\section{LANDASAN TEOR}

\subsection{Akuntansi}

Menurut Hery (2009:1), "akuntansi adalah sebuah aktivitas jasa, di mana fungsinya adalah memberikan informasi mengenai posisi keuangan dan hasil kinerja perusahaan, yang dimaksudkan akan menjadi berguna dalam pengambilan keputusan ekonomi".

Sedangkan menurut Indratno (2013:8), "akuntansi adalah sebuah aktivitas yang menjadi bagian dari sistem informasi keuangan guna mengahasilkan laporan yang komprehensif, detail dan akurat kepada pihakpihak tertentu yang memiliki kepentingan terhadap aktivitas ekonomi dan kondisi finansial perusahaan".

\subsection{Analisa Laporan Keuangan}

Menurut Hery (2015:490), "analisis laporan keuangan merupakan suatu proses untuk membedah laporan keuangan ke dalam unsurunsurnya dan menelaah masing-masing dari unsur tersebut dengan tujuan untuk memperoleh pengertian dan pemahaman yang tepat dan baik atas laporan keuangan itu sendiri".

Menurut Rudianto (2009:190), "analisis laporan keuangan adalah meneliti hubungan yang ada diantara unsur-unsur dalam laporan keuangan dan membandingkan unsur-unsur pada laporan keuangan tahun berjalan dengan unsur-unsur yang sama tahun lalu atau angka pembanding lain serta menjelaskan penyebab perubahannya".

\subsection{Rasio Keuangan}

Menurut Horne dan John (2012:163), "rasio keuangan adalah indeks yang menghubungkan dua angka akuntansi dan dapat membagi satu angka dengan angka yang lainnya". Sedangkan menurut Kasmir (2012:104), "rasio keuangan merupakan kegiatan membandingkan angka-angka yang ada dalam laporan keuangan dengan cara membagi satu angka dengan angka lainnya".

\subsection{Likuiditas}

Kasmir (2012:110) mengemukakan, "rasio likuiditas (liquidity ratio) yaitu rasio yang menggambarkan kemampuan perusahaan dalam memenuhi kewajiban (hutang) jangka pendek". Sedangkan pendapat Riyanto (2009:25) menyatakan, "likuiditas adalah masalah yang berhubungan dengan masalah kemampuan suatu perusahaan untuk memenuhi kewajiban finansialnya yang segera harus dipenuhi".

\subsection{Profitabilitas}

Menurut menurut Astuti (2004:36), "profitabilitas adalah kemampuan suatu perusahaan untuk menghasilkan laba". Sedangkan menurut Sudana (2011:22), "profitabilitas yaitu mengukur kemampuan perusahaan untuk menghasilkan laba dengan menggunakan sumber-sumber yang dimiliki perusahaan, seperti aktiva, modal, atau penjualan perusahaan".

\subsection{Kebijakan Dividen}

Menurut Musthafa (2017:141), "kebijakan dividen adalah keputusan apakah laba yang diperoleh perusahaan akan dibagikan kepada pemegang saham sebagai dividen atau akan ditahan dalam bentuk laba ditahan guna pembiayaan investasi di masa yang akan datang". Sedangkan menurut Astuti (2004:145), "kebijakan dividen adalah keputusan untuk membagi laba atau menahannya guna diinvestasikan kembali di dalam perusahaan".

\subsection{Nilai Perusahaan}

Menurut Brigham dan Joel (2010:150), "nilai perusahaan adalah rasio yang menghubungkan harga saham perusahaan dengan laba, arus kas dan nilai buku per sahamnya". Sedangkan menurut Sudana (2011:8), "nilai perusahaan adalah nilai sekarang dari arus pendapatan atau kas yang diharapkan diterima pada masa yang akan datang".

\subsection{Pengaruh Likuiditas dan Profitabilitas terhadap Nilai Perusahaan}

Dari pendapat Brigham dan Joel (2010:150) juga menunjukkan bahwa secara simultan likuiditas dan profitabilitas berpengaruh signifikan terhadap nilai perusahaan. Hal ini diperkuat dari hasil penelitian Mery (2017), "menyatakan bahwa likuiditas dan profitabilitas berpengaruh signifikan terhadap nilai perusahaan". Untuk mendapatkan nilai perusahaan yang baik maka perusahaan harus mampu mengelola rasio likuiditas dan profitabilitasnya dengan baik, sehingga nilai pasar dan harga sahamnya juga semakin baik.

\subsection{Pengaruh Likuiditas dan Profitabilitas terhadap Nilai Perusahaan yang Dimoderasi \\ Kebijakan Dividen}

Kebijakan dividen yang optimal pada suatu perusahaan yaitu yang mampu menciptakan keseimbangan diantara dividen saat ini sehingga memaksimumkan harga saham. Menurut Myron Gordon dan John Lintner berdasarkan teori bird in the hand dalam 
Sudana (2011:169), "kebijakan dividen berpengaruh positif terhadap harga pasar saham".

Hal ini diperkuat dari hasil penelitian Lestari (2017:68), "kebijakan dividen memperkuat hubungan likuiditas, leverage, dan profitabilitas terhadap nilai perusahaan". Kebijakan dividen memiliki dua kepentingan yaitu kepentingan meningkatkan nilai perusahaan dan stabilitas perusahaan jadi kebijakan dividen dapat dijadikan sebagai variabel moderasi karena merupakan bagian yang menyatu dengan keputusan pendanaan perusahaan yang menyangkut pada pembelanjaan internal perusahaan.

\section{PEMBAHASAN}

\subsection{Analisis}

\subsubsection{Analisis Deskripsi Kualitatif}

3.1.1.1. Likuiditas pada Perusahaan Sub Sektor Makanan dan Minuman Periode 2013-2016

Berikut ini disajikan data likuiditas perusahaan Sub Sektor Makanan dan Minuman yang diukur dengan Current Ratio $(\mathrm{CR})$.

Tabel 3.1

Likuiditas pada Perusahaan Sub Sektor Makanan dan Minuman Periode 2013-2016

\begin{tabular}{|c|c|c|c|c|c|}
\hline $\begin{array}{c}\text { KODE } \\
\text { EMITEN }\end{array}$ & $\mathbf{2 0 1 3}$ & $\mathbf{2 0 1 4}$ & $\mathbf{2 0 1 5}$ & $\mathbf{2 0 1 6}$ & $\begin{array}{c}\text { RATA-RATA } \\
\text { CR (kali) }\end{array}$ \\
\hline INDF & 1,67 & 1,81 & 1,71 & 1,51 & $\mathbf{1 , 6 7}$ \\
\hline ROTI & 1,14 & 1,37 & 2,05 & 2,96 & $\mathbf{1 , 8 8}$ \\
\hline SKLT & 1,23 & 1,18 & 1,19 & 1,32 & $\mathbf{1 , 2 3}$ \\
\hline $\begin{array}{c}\text { RATA- } \\
\text { RATA }\end{array}$ & $\mathbf{1 , 3 5}$ & $\mathbf{1 , 4 5}$ & $\mathbf{1 , 6 5}$ & $\mathbf{1 , 9 3}$ & $\mathbf{1 , 5 9}$ \\
\hline \multicolumn{5}{|c|}{ Nilai Minimum (CR) } & $\mathbf{1 , 1 4}$ \\
\hline \multicolumn{5}{|c|}{ Nilai Maksimum (CR) } & $\mathbf{2 , 9 6}$ \\
\hline
\end{tabular}

Sumber: Data Diolah

Dari tabel 3.1, tampak keadaan rata-rata likuiditas yang diukur dengan $\mathrm{CR}$ pada perusahaan Sub Sektor Makanan dan Minuman yang Terdaftar di Bursa Efek Indonesia cenderung meningkat. Hal ini disebabkan jumlah aktiva lancar berfluktuasi dan cenderung meningkat yang diikuti dengan utang lancar.

3.1.1.2. Profitabilitas pada Perusahaan Sub Sektor Makanan dan Minuman Periode 2013-2016

Berikut ini profitabilitas Perusahaan Sub Sektor Makanan dan Minuman yang diukur dengan rasio ROA disajikan dalam Tabel 3.2. Tabel 3.2

Profitabilitas pada Perusahaan Sub Sektor Makanan dan Minuman Periode 2013-2016

\begin{tabular}{|c|c|c|c|c|c|}
\hline $\begin{array}{l}\text { KODE } \\
\text { EMITEN }\end{array}$ & 2013 & 2014 & 2015 & 2016 & $\begin{array}{c}\text { RATA-RATA } \\
\text { ROA } \\
\text { (kali) }\end{array}$ \\
\hline INDF & 0,04 & 0,06 & 0,04 & 0,06 & 0,05 \\
\hline ROTI & 0,09 & 0,09 & 0,10 & 0,10 & 0,09 \\
\hline SKLT & 0,04 & 0,05 & 0,05 & 0,04 & 0,04 \\
\hline $\begin{array}{l}\text { RATA- } \\
\text { RATA }\end{array}$ & 0,06 & 0,07 & 0,06 & 0,07 & 0,06 \\
\hline \multicolumn{5}{|c|}{ Nilai Minimum (ROA) } & 0,04 \\
\hline \multicolumn{5}{|c|}{ Nilai Maksimum (ROA) } & 0,10 \\
\hline
\end{tabular}

Sumber : Data Diolah

Dari tabel 3.2, tampak keadaan rata-rata profitabilitas yang diukur dengan ROA pada
Perusahaan Sub Sektor Makanan dan Minuman periode 2013-2016 berfluktuasi dan cenderung meningkat. Hal ini disebabkan total aset meningkat lebih tinggi diikuti meningkatnya laba bersih stelah pajak.

3.1.1.3. Kebijakan Dividen pada Perusahaan Sub Sektor Makanan dan Minuman Periode 2013-2016

Berikut ini kebijakan dividen pada Perusahaan Sub Sektor Makanan dan Minuman yang diukur dengan rasio DPR disajikan dalam Tabel 3.3.

Tabel 3.3

Kebijakan Dividen pada Perusahaan Sub Sektor Makanan dan Minuman Periode 2013-2016

\begin{tabular}{|c|c|c|c|c|c|}
\hline $\begin{array}{c}\text { KODE } \\
\text { EMITEN }\end{array}$ & $\mathbf{2 0 1 3}$ & $\mathbf{2 0 1 4}$ & $\mathbf{2 0 1 5}$ & $\mathbf{2 0 1 6}$ & $\begin{array}{c}\text { RATA-RATA } \\
\text { DPR } \\
\text { (kali) }\end{array}$ \\
\hline INDF & 0,50 & 0,59 & 0,57 & 0,54 & $\mathbf{0 , 5 5}$ \\
\hline ROTI & 0,10 & 0,15 & 0,20 & 0,25 & $\mathbf{0 , 1 7}$ \\
\hline SKLT & 0,24 & 0,21 & 0,20 & 0,17 & $\mathbf{0 , 2 1}$ \\
\hline $\begin{array}{c}\text { RATA- } \\
\text { RATA }\end{array}$ & $\mathbf{0 , 2 8}$ & $\mathbf{0 , 3 2}$ & $\mathbf{0 , 3 3}$ & $\mathbf{0 , 3 2}$ & $\mathbf{0 , 3 1}$ \\
\hline \multicolumn{5}{|c|}{ Nilai Minimum (DPR) } & $\mathbf{0 , 1 0}$ \\
\hline \multicolumn{5}{|c|}{ Nilai Maksimum (DPR) } & $\mathbf{0 , 5 9}$ \\
\hline
\end{tabular}

Sumber: Data Diolah

Dari tabel 3.3, tampak keadaan ratarata kebijakan dividen yang diukur dengan DPR pada perusahaan Sub Sektor Makanan dan Minuman yang Terdaftar di Bursa Efek Indonesia berfluktuasi dan cenderung meningkat. Hal ini disebabkan oleh DPS yang dibagikan berfluktuasi dan cenderung meningkat yang diikuti oleh EPS.

3.1.1.4. Nilai Perusahaan pada Perusahaan Sub Sektor Makanan dan Minuman Periode 2013-2016

Berikut ini nilai perusahaan Perusahaan Sub Sektor Makanan dan Minuman yang diukur dengan menggunakan rasio PBV disajikan dalam Tabel 3.4 .

Tabel 3.4

Nilai Perusahaan pada Perusahaan Sub Sektor Makanan dan Minuman Periode 2013-2016

\begin{tabular}{|c|c|c|c|c|c|}
\hline $\begin{array}{c}\text { KODE } \\
\text { EMITEN }\end{array}$ & $\mathbf{2 0 1 3}$ & $\mathbf{2 0 1 4}$ & $\mathbf{2 0 1 5}$ & $\mathbf{2 0 1 6}$ & $\begin{array}{c}\text { RATA-RATA } \\
\text { PBV } \\
\text { (kali) }\end{array}$ \\
\hline INDF & 2,45 & 2,31 & 1,67 & 2,40 & $\mathbf{2 , 2 1}$ \\
\hline ROTI & 6,56 & 7,30 & 5,39 & 5,79 & $\mathbf{6 , 2 6}$ \\
\hline SKLT & 0,89 & 1,35 & 1,68 & 0,72 & $\mathbf{1 , 1 6}$ \\
\hline $\begin{array}{c}\text { RATA- } \\
\text { RATA }\end{array}$ & $\mathbf{3 , 3 0}$ & $\mathbf{3 , 6 5}$ & $\mathbf{2 , 9 1}$ & $\mathbf{2 , 9 7}$ & $\mathbf{3 , 2 1}$ \\
\hline \multicolumn{4}{|c|}{ Nilai Minimum (PBV) } & $\mathbf{0 , 7 2}$ \\
\hline \multicolumn{3}{|c|}{ Nilai Maksimum (PBV) } & $\mathbf{7 , 3 0}$ \\
\hline
\end{tabular}

Sumber : Data Diolah

Dari tabel 3.4, tampak keadaan rata-rata nilai perusahaan yang diukur dengan PBV pada perusahaan Sub Sektor Makanan dan Minuman yang terdaftar pada Bursa Efek Indonesia periode 2013-2016 mengalami fluktuasi dan cenderung menurun. Hal ini disebabkan oleh meningkatnya jumlah ekuitas biasa.

3.1.2. Analisis Deskrisptif Kuantitatif

3.1.2.1. Regresi Linier Berganda

1. Regresi Linier Berganda Tanpa Moderating 
Hasil analisis linear berganda tanpa variabel moderating dapat dilihat di Tabel 3.5.

Tabel 3.5

Hasil Analisis Regresi Linier Berganda Tanpa Moderating

\begin{tabular}{|ll|r|r|r|}
\hline \multicolumn{1}{|l|}{ Model } & \multicolumn{2}{|c|}{$\begin{array}{c}\text { Unstandardized } \\
\text { Coefficients }\end{array}$} & $\begin{array}{c}\text { Standardized } \\
\text { Coefficients }\end{array}$ \\
\cline { 2 - 5 } & \multicolumn{1}{|c|}{ B } & Std. Error & \multicolumn{1}{c|}{ Beta } \\
\hline \multirow{4}{*}{1} & (Constant) & $-1,944$ & 1,024 & \\
& CR &,- 660 &, 653 &,- 145 \\
& ROA & 98,474 & 14,271 &, 990 \\
\hline
\end{tabular}

Sumber: Hasil Pengolahan Data

Berdasarkan Tabel 3.5, model persamaan regresi yang diperoleh adalah sebagai berikut:

$$
\hat{\mathrm{Y}}=-1,944-0,660 \mathrm{X}_{1}+98,474 \mathrm{X}_{2}
$$

Artinya likuiditas berpengaruh negatif dan profitabilitas berpengaruh positif terhadap nilai perusahaan pada Perusahaan Sub Sektor Makanan dan Minuman yang terdaftar pada Bursa Efek Indonesia periode 2013-2016.

\section{Regresi Linier Berganda dengan} Variabel Moderating

Hasil regresi linear berganda dengan variabel moderating dapat dilihat pada Tabel 3.6:

Tabel 3.6

Hasil Analisis Regresi Linier Berganda dengan Variabel Moderating

\begin{tabular}{|l|r|r|r|}
\hline Model & \multicolumn{2}{|c|}{$\begin{array}{c}\text { Unstandardized } \\
\text { Coefficients }\end{array}$} & $\begin{array}{c}\text { Standardize } \\
\text { d } \\
\text { Coefficients }\end{array}$ \\
\cline { 2 - 4 } & \multicolumn{1}{|c|}{ B } & Std. Error & \multicolumn{1}{c|}{ Beta } \\
\hline (Constant) & $-2,571$ & 4,163 & \\
CR & $-1,950$ & 2,206 &,- 428 \\
ROA & 144,662 & 27,106 & 1,455 \\
DPR & 1,129 & 17,713 &, 088 \\
INTERAKS & 6,939 & 9,103 & 1,015 \\
I_1 & - & 108,460 &,- 973 \\
INTERAKS & 228,964 & & \\
I_2 & & & \\
\hline
\end{tabular}

Sumber: Hasil Pengolahan Data

Berdasarkan Tabel 3.6, model persamaan regresi yang diperoleh adalah sebagai berikut: $\hat{Y}=-2,571-1,950 X_{1}+144,662 X_{2}+1,129 X_{3}+$ $6,939 X_{1} X_{3}-228,964 X_{2} X_{3}+$

Artinya kebijakan dividen dapat memperkuat hubungan antara likuiditas dengan nilai perusahaan dan memperlemah hubungan profitabilitas dengan nilai perusahaan pada Perusahaan Sub Sektor Makanan dan Minuman yang terdaftar pada Bursa Efek Indonesia periode 2013-2016.

\subsubsection{Koefisien Korelasi dan Determinasi \\ 1. Koefisien Korelasi dan Determinasi Tanpa Moderating}

Hasil analisis koefisien korelasi dan determinasi tanpa variabel moderating dapat dilihat pada Tabel 3.7.

$$
\text { Tabel } 3.7
$$

Koefisien Korelasi dan Koefisien Determinasi Tanpa Moderating

\begin{tabular}{|l|l|l|l|}
\hline Model & $\mathrm{R}$ & R Square & $\begin{array}{c}\text { Adjusted R } \\
\text { Square }\end{array}$ \\
\hline
\end{tabular}

\begin{tabular}{|l|r|r|r|}
\hline 1 &, $927^{\mathrm{a}}$ &, 860 &, 829 \\
\hline Sumber: Hasil Pengolahan Data &
\end{tabular}

Dari Tabel 3.7, nilai $r$ adalah 0,927 yang berarti terdapat korelasi atau hubungan yang sangat kuat antara variabel dependen (PBV) dengan variabel independennya (CR dan ROA). Sementara koefisien determinasi ( $R$ Square) sebesar 0,860, yang berarti $86 \%$ dari variabel nilai perusahaan dijelaskan oleh variabel likuiditas dan profitabilitas sisanya $14 \%$ dijelaskan oleh variabel lain yang tidak diteliti dalam penelitian ini.

\section{Koefisien Korelasi dan Determinasi} dengan Variabel Moderating

Hasil analisis koefisien korelasi dan determinasi dengan variabel moderating dapat dilihat pada Tabel 3.8.

Tabel 3.8

Koefisien Korelasi dan Koefisien Determinasi

\begin{tabular}{|l|r|r|r|}
\multicolumn{1}{|c|}{ dengan Variabel Moderating } \\
\hline Model & $\mathrm{R}$ & R Square & \multicolumn{2}{|c|}{$\begin{array}{c}\text { Adjusted R } \\
\text { Square }\end{array}$} \\
\hline 1 &, $967^{\mathrm{a}}$ &, 934 & \multicolumn{1}{c|}{, 879} \\
\hline
\end{tabular}

Sumber: Hasil Pengolahan Data

Dari Tabel 3.8, nilai $r$ adalah 0,967 yang berarti terdapat korelasi atau hubungan yang sangat kuat antara CR dan ROA dengan PBV yang dimoderasi oleh DPR. Sementara koefisien determinasi ( $R$ Square) sebesar 0,934 , yang berarti $93,4 \%$ dari variabel nilai perusahaan dijelaskan oleh variabel likuiditas, profitabilitas dan kebijakan dividen sisanya $6,6 \%$ dijelaskan oleh variabel lain yang tidak diteliti dalam penelitian ini.

\subsubsection{Uji Hipotesis}

\section{Uji Hipotesis Tanpa Variabel Moderating}

1) Uji Simultan (F)

Hasil uji F tanpa variabel moderating dapat dilihat pada Tabel 3.9.

Tabel 3.9

Hasil Uji $F_{\text {hitung }}$

\begin{tabular}{|ll|c|c|}
\hline Model & & $\mathrm{F}$ & Sig. \\
\hline 1 & $\begin{array}{l}\text { Regression } \\
\text { Residual } \\
\text { Total }\end{array}$ & 27,596 &, $000^{\mathrm{b}}$ \\
\hline
\end{tabular}

Sumber: Hasil Pengolahan Data

Dari Tabel 3.9 di atas, diperoleh nilai signifikansi $0,000<0,05$ maka $\mathrm{H}_{0}$ ditolak, berarti likuiditas dan profitabilitas berpengaruh signifikan terhadap nilai perusahaan pada Perusahaan Sub Sektor Makanan dan Minuman yang terdaftar di Bursa Efek Indonesia.

2) Uji Parsial (Uji t)

Hasil uji t tanpa variabel moderating dapat dilihat pada Tabel 3.10

Tabel 3.10

\begin{tabular}{|c|c|c|}
\hline Model & $\bar{T}$ & Sig. \\
\hline $\begin{array}{ll}1 & \text { (Constant) } \\
& \text { CR }\end{array}$ & $\begin{array}{l}-1,899 \\
-1,010\end{array}$ & $\begin{array}{l}\text {,090 } \\
\text {,339 }\end{array}$ \\
\hline
\end{tabular}

Perkiraan Nilai $t_{\text {hitung }}$ Tanpa Moderating 
ROA | 6,900 | , 000

Sumber: Hasil Pengolahan Data (SPSS)

Dari Tabel 3.10 Likuiditas mempunyai nilai signifikansi $0,339<0,05$ maka $\mathrm{H}_{0}$ diterima, artinya likuiditas berpengaruh tidak signifikan terhadap nilai perusahaan. Profitabilitas mempunyai nilai signifikansi 0,000 < 0,05 maka $\mathrm{H}_{0}$ ditolak, artinya profitabilitas berpengaruh signifikan terhadap nilai perusahaan pada Perusahaan Sub Sektor Makanan dan Minuman yang terdaftar di Bursa Efek Indonesia.

2. Uji Hipotesis dengan Variabel Moderating

Hasil uji t dengan variabel moderating dapat dilihat pada Tabel 3.11.

Tabel 3.11

Perkiraan Nilai thitung dengan Moderating

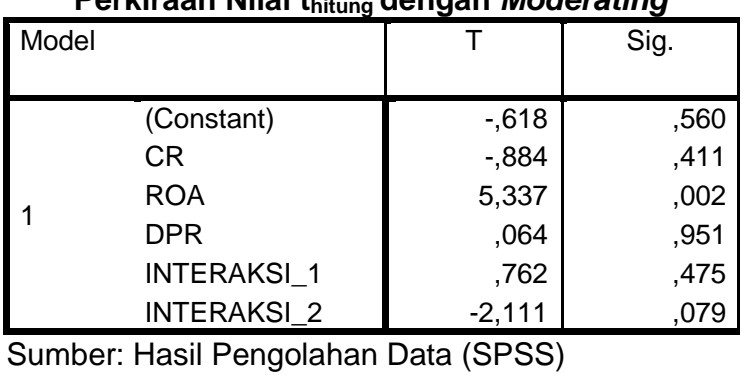

Dari Tabel 3.11, dapat dilihat untuk variabel likuiditas dengan kebijakan dividen sebagai variabel moderating mempunyai nilai signifikansi $0,762<0,05$ maka $\mathrm{H}_{0}$ diterima, artinya kebijakan dividen mampu memoderasi namun tidak signifikan hubungan likuiditas dengan nilai perusahaan. Untuk variabel profitabilitas dengan kebijakan dividen sebagai variabel moderating mempunyai nilai signifikansi $0,079<0,05$ maka $\mathrm{H}_{0}$ diterima, artinya kebijakan dividen mampu memoderasi namun tidak signifikan hubungan profitabilitas dengan nilai perusahaan pada Perusahaan Sub Sektor Makanan dan Minuman yang terdaftar pada Bursa Efek Indonesia.

\subsection{Evaluasi}

3.2.1. Evaluasi Likuiditas pada Perusahaan Sub Sektor Makanan dan Minuman Periode 2013-2016

Hasil penelitian menunjukkan bahwa kondisi Current Ratio (CR) pada Perusahaan Sub Sektor Makanan dan Minuman yang terdaftar di Bursa Efek Indonesia periode 2013-2016 cederung meningkat. Hal ini disebabkan jumlah aset lancar berfluktuasi dan cenderung meningkat yang diikuti dengan utang lancar. Untuk mempertahankankan nilai likuiditas maka perusahaan perlu mengelola aset lancar dan utang lancar secara efisien dengan cara menjual persediaan dan melakukan penagihan terhadap piutang usaha yang telah jatuh tempo yang akan menghasilkan kas dan digunakan untuk membayar kewajiban jangka pendeknya.

\subsubsection{Evaluasi Profitabilitas pada \\ Perusahaan Sub Sektor Makanan dan \\ Minuman Periode 2013-2016}

Hasil penelitian pada gambar, diketahui bahwa Return On Assets (ROA) berfluktuasi dan cenderung meningkat. Hal ini disebabkan total aset meningkat lebih tinggi diikuti meningkatnya laba bersih setelah pajak. Untuk mempertahankan nilai Return On Assets yang tinggi maka sebaiknya manajemen perusahaan menggunakan asetnya secara efisien juga lebih produktif mengelola asetnya dalam meningkatkan laba perusahaan, dan manajemen perusahaan sebaiknya juga meningkatkan volume penjualan tunai laba yang dihasilkan akan meningkat dengan baik.

3.2.3. Evaluasi Kebijakan Dividen pada

Perusahaan Sub Sektor Makanan dan Minuman Periode 2013-2016

Hasil penelitian ini, rata-rata kebijakan dividen pada Perusahaan Sub Sektor Makanan dan Minuman yang terdaftar di Bursa Efek Indonesia pada tahun 2013-2016 mengalami fluktuasi dan cenderung meningkat. Hal ini disebabkan oleh DPS yang dibagikan berfluktuasi dan cenderung meningkat yang diikuti oleh EPS. Untuk mempertahankan dan meningkatkan kebijakan dividen, sebaiknya perusahaan menjaga profitabilitas tetap meningkat setiap tahunnya dan memperluas pengungkapan informasinya untuk memberikan sinyal yang baik bagi investor dan calon investor.

\subsubsection{Evaluasi Nilai Perusahaan pada} Perusahaan Sub Sektor Makanan dan Minuman Periode 2013-2016

Hasil penelitian, menunjukkan kondisi nilai perusahaan Sub Sektor Makanan dan Minuman periode 2013-2016 mengalami fluktuasi cenderung menurun. Hal ini disebabkan oleh meningkatnya jumlah ekuitas biasa. Untuk meningkatkan nilai perusahaan sebaiknya perusahaan mampu menjaga kepercayaan investor terhadap perusahaan. Perusahaan juga sebaiknya melakukan pengendalian yang baik terhadap manajemen aset yang dimiliki perusahaan serta pandangan masyarakat akan perusahaan itu sendiri.

3.2.5. Evaluasi Pengaruh Likuiditas dan Profitabilitas terhadap Perusahaan pada Perusahaan Sub Sektor Makanan dan Minuman Periode 2013-2016

Berdasarkan hasil regresi linear berganda tanpa variabel moderating, dapat diketahui bahwa likuiditas berpengaruh negatif dan profitabilitas berpengaruh positif terhadap nilai perusahaan. Hal ini dapat dilihat dari persamaan regresi linear berganda tanpa variabel moderating yaitu: $\hat{Y}=-1,944+0,660 X_{1}$ $+\mathbf{9 8}, \mathbf{4 7 4} X_{2}$. Dari hasil tersebut dapat dijelaskan bahwa nilai koefisien regresi sebesar $-1,944$ yang secara sistematis menyatakan bahwa jika 
likuiditas dan profitabilitas sama dengan nol maka nilai perusahaan adalah sebesar -1,944.

Likuiditas sebesar $-0,660$ berarti bahwa setiap variabel likuiditas meningkat sebesar satu satuan, nilai perusahaan akan menurun sebesar 0,660 satuan. Profitabilitas sebesar 98,474 berarti bahwa setiap variabel profitabilitas meningkat sebesar satu satuan, nilai perusahaan akan meningkat sebesar 98,474 satuan

3.2.6. Evaluasi Pengaruh Likuiditas dan Profitabilitas terhadap Nilai Perusahaan dengan Kebijakan Dividen sebagai Variabel Moderating pada Perusahaan Sub Sektor Makanan dan Minuman Periode 20132016

Berdasarkan hasil uji $t$, diperoleh hasil interaksi antara likuiditas dengan kebijakan dividen yaitu nilai $t_{\text {hitung }}$ sebesar 0,762 menunjukkan bahwa $t_{\text {hitung }}<t_{\text {tabel }}(0,762<$ $2,44691)$ atau dengan taraf signifikan 0,475 > 0,05 , maka $\mathrm{H}_{0}$ diterima, artinya kebijakan dividen mampu memoderasi namun tidak signifikan hubungan likuiditas dengan nilai perusahaan.

Interaksi antara profitabilitas dengan kebijakan dividen memiliki nilai $t_{\text {hitung }}$ sebesar $2,111 t_{\text {hitung }}>t_{\text {tabel }}(-2,111>2,44691)$ atau dengan taraf signifikan $0,079>0,05$, maka $\mathrm{H}_{0}$ diterima, artinya kebijakan dividen mampu memoderasi namun tidak signifikan hubungan profitabilitas dengan nilai perusahaan.

\section{KESIMPULAN DAN SARAN}

\subsection{Kesimpulan}

1. Likuiditas yang diukur dengan Current Ratio (CR) cenderung meningkat. Hal ini disebabkan jumlah aktiva lancar berfluktuasi dan cenderung meningkat yang diikuti dengan utang lancar.

2. Profitabilitas yang diukur dengan Return On Assets (ROA) mengalami fluktuasi setiap tahunnya dan cenderung meningkat. Hal ini disebabkan total aset meningkat lebih tinggi diikuti meningkatnya laba bersih setelah pajak.

3. Kebijakan dividen sebagai variabel moderating yang diukur dengan Dividend Payout Ratio (DPR) mengalami fluktuasi setiap tahunnya dan cenderung meningkat. Hal ini disebabkan oleh dividen per saham yang dibagikan befluktuasi dan cenderung meningkat yang diikuti oleh laba per saham.

4. Nilai perusahaan yang diukur dengan Price to Book Value (PBV) mengalami fluktuasi setiap tahunnya dan cenderung menurun. Hal ini disebabkan oleh meningkatnya jumlah ekuitas biasa.

5. Hasil persamaan regresi linier berganda yaitu:

1) Hasil pengujian tanpa moderating menunjukkan bahwa likuiditas berpengaruh negatif dan profitabilitas berpengaruh positif terhadap nilai perusahaan pada Perusahaan Sub Sektor Makanan dan Minuman yang terdaftar di Bursa Efek Indonesia periode 2013-2016.

2) Hasil pengujian dengan moderating menunjukkan bahwa kebijakan dividen dapat memperkuat hubungan antara likuiditas dengan nilai perusahaan dan memperlemah hubungan profitabilitas dengan nilai perusahaan pada Perusahaan Sub Sektor Makanan dan Minuman yang terdaftar di Bursa Efek Indonesia untuk periode 2013-2016.

6. Hasil uji koefisien korelasi dan determinasi:

1) Hasil uji koefisien korelasi dan determinasi tanpa moderating menunjukkan bahwa terdapat korelasi atau hubungan yang sangat kuat antara likuiditas, profitabilitas dan nilai perusahaan. Sementara untuk hasil determinasi diketahui bahwa nilai perusahaan dapat dipengaruhi oleh likuiditas dan profitabilitas.

2) Hasil uji koefisien korelasi dan determinasi dengan moderating menunjukkan bahwa terdapat korelasi atau hubungan yang sangat kuat antara likuiditas, profitabilitas, kebijakan dividen dan nilai perusahaan. Sementara untuk hasil determinasi diketahui bahwa nilai perusahaan dapat dipengaruhi oleh likuiditas, profitabilitas dan kebijakan dividen.

7. Hasil hipotesis dengan uji $F$ tanpa moderating bahwa secara simultan dapat disimpulkan likuiditas dan profitabilitas berpengaruh signifikan terhadap nilai perusahaan pada Perusahaan Sub Sektor Makanan dan Minuman yang terdaftar di Bursa Efek Indonesia.

8. Hasil hipotesis dengan uji t bahwa secara parsial diperoleh:

1) Hasil hipotesis tanpa moderating dapat disimpulkan bahwa likuiditas berpengaruh tidak signifikan terhadap nilai perusahaan. Untuk profitabilitas berpengaruh signifikan terhadap nilai perusahaan pada Perusahaan Sub Sektor Makanan dan Minuman yang terdaftar di Bursa Efek Indonesia.

2) Hasil hipotesis dengan moderating dapat disimpulkan bahwa interaksi likuiditas dengan kebijakan dividen dapat dikatakan bahwa kebijakan dividen mampu memoderasi namun tidak signifikan hubungan likuiditas dengan nilai perusahaan. Hasil interaksi profitabilitas dengan kebijakan dividen dapat dikatakan bahwa kebijakan dividen mampu memoderasi namun 
tidak signifikan hubungan profitabilitas dengan nilai perusahaan pada Perusahaan Sub Sektor Makanan dan Minuman yang terdaftar di Bursa Efek Indonesia.

4.2. Saran

1. Sebaiknya perusahaan perlu mengelola aktiva lancar dan utang lancar secara efisien dengan cara menjual persediaan dan melakukan penagihan terhadap piutang usaha yang telah jatuh tempo.

2. Sebaiknya manajemen perusahaan lebih produktif mengelola asetnya dalam meningkatkan laba perusahaan, dan juga meningkatkan volume penjualan tunai agar laba yang dihasilkan akan meningkat dengan baik.

3. Sebaiknya perusahaan menjaga profitabilitas tetap meningkat setiap tahunnya dan memperluas pengungkapan informasinya untuk memberikan sinyal yang baik bagi investor dan calon investor.

4. Sebaiknya perusahaan mampu menjaga kepercayaan investor terhadap perusahaan. Perusahaan juga sebaiknya mempertahankan tingkat profitabilitas agar terus meningkat dan lebih meningkatkan pembagian dividen setiap tahunnya.

\section{DAFTAR PUSTAKA}

Astuti, Dewi. 2004. Manajemen Keuangan Perusahaan. Jakarta: Ghalia Indonesia.

Brigham, Eugene $F$, dan Joel F. Houston. 2010, Dasar-dasar Manajemen
Keuangan, Buku1, Edisi Pertama, Jakarta:Salemba Empat. Jakarta: Erlangga

Hery. 2009. Akuntansi Keuangan Menengah 1, Cetakan pertama. Jakarta: PT Bumi Aksara.

2015. Teori Akuntansi. Jakarta: Penerbit Erlangga.

Horne, James C.Van dan John M.Wachowiccz, Jr. 2012. Prinsip-Prinsip Manajemen Keuangan. Buku 1, Edisi XIII. Jakarta: Salemba Empat.

Indratno, Albertus. 2013. Prinsip-Prinsip Dasar Akuntansi. Jakarta: Dunia Cerdas.

Kasmir. 2012. Analisis Laporan Keuangan. Jakarta: Rajawali Pers.

Lestari, Erna Yuliana. 2017. Pengaruh Likuiditas, Leverage, Dan Profitabilitas Terhadap Nilai Perusahaan Dengan Kebijakan Dividen Sebagai Variabel Moderating. Yogyakarta: Muhammadiyah.

Musthafa. 2017. Manajemen Keuangan. Edisi Pertama. Yogyakarta: ANDI.

Riyanto, Bambang. 2009. Dasar-dasar Pembelanjaan Perusahaan. Edisi Empat. Yogyakarta: BPFE.

Sudana. I Made. 2011. Manajemen Keuangan Perusahaan Teori dan Praktek. Jakarta : Penerbit Erlangga. 